\title{
PENGEMBANGAN DESA WISATA BERBASIS MULTIKULTURAL DI DESA PATOMAN
}

\author{
I Kadek Yudiana ${ }^{1^{*}}$, Andika Wahyudiono ${ }^{1}$ \\ ${ }^{1}$ Universitas 17 Agustus 1945 Banyuwangi, Indonesia \\ *email: ${ }^{1}$ ikadekyudiana@untag-banyuwangi.ac.id
}

\begin{abstract}
Abstrak
Kemultikulturan merupakan suatu kekuatan dan kelemahan bagi sebuah bangsa oleh karena itu, kemultikulturan harus dikelola untuk menghindari disintegrasi. Salah satu solusi alternative dalam mengelola kemultikulturan pada pedesaan adalah dengan cara mengemas kemultikulturan tersebut menjadi daya tarik wisatawa. Tujuan penelitian ini untuk menganalisis wujud multikultural masyarakat Desa Patoman Blimbingsari, Banyuwangi dan menganalisis model desa wisata berbasis multikulturalisme di Desa Patoman, Blimbingsari, Banyuwangi. Metode penelitan yang digunakan adalah Deskriftif Kualitatif. Teknik pengambilan data berupa wawancara mendalam, observasi langsung, dan studi dokumen. Sedangkan teknik analisis data menggunakan teknik analisis data kualitatif yang meliputi pengumpulan data, reduksi data, sajian data, dan penarikan simpulan/verifikasi. Hasil penelitian menunjukkan bahwa wujud kemultikulturan terintegrai dalam nilai-nilai yang terkandung dalam kemultikulturan masyarakat Desa Patoman meliputi: Nilai Social, Simpati, Toleransi dan Empati, Religious, Nasionalisme, Gotong Royong, Demokrasi, Bersahabat/Komunikatif, kecintaan terhadap lingkungan, cinta damai, dan peduli sosial. Selain itu, terjadi interaksi intra dan antar agama dengan pola interaksi asosiatif. Sedangkan model desa wisata berbaisis multikultur yang berkembang menggunakan model terpadu dan berkelanjutan. Hal ini dapat dilihat dari indikator yang ada berupa demand, suplay, dan ekternal factor dengan didukung oleh sistem pemberdayaan masyarakat desa.
\end{abstract}

Kata Kunci: Pengembangan; Desa Wisata; Multikultural

\begin{abstract}
Multiculturalism is a strength and weakness for a nation. Therefore, Multiculturalism must be managed to avoid disintegration. One alternative solution in managing culture in rural areas is by packaging the Multiculturalism into a tourist attraction. The objectives of this study were to analyze the multicultural form of the people of Patoman Blimbingsari Village, Banyuwangi, analyzing the tourism village model based on Multiculturalism in Patoman Village, Blimbingsari, Banyuwangi. The research method used is descriptive qualitative. The data collection techniques were in-depth interviews, direct observation, and document study. Simultaneously, the data analysis technique uses qualitative data analysis techniques, including data collection, data reduction, data presentation, and drawing conclusions/verification. The results showed that the integrated culture of the values contained in the culture of the people of Patoman Village includes: Social Values, Sympathy, Tolerance and Empathy, Religion, Nationalism, Mutual Cooperation, Democracy, Friendly/Communicative, love of the environment, love of peace, and social care. Besides, there are intra-religious and inter-religious interactions with associative interaction patterns. Meanwhile, the developing multicultural model of tourism village uses an integrated and sustainable model. This can be seen from the existing indicators in the form of demand, supply, and external factors supported by the village community empowerment system.
\end{abstract}

Keywords: Development; Tourism Village; Multiculturalis

\section{PENDAHULUAN}

Meminjam istilahnya Suratman

(2013) mengatakan Indonesia adalah bangsa yang Multikultur/Majemuk. Masyarakat majemuk tersusun oleh keragaman kelompok etnik atau suku bangsa beserta tradisi dan budayanya, tidak hanya berpeluang menjadikan bangsa Indonesia menjadi negara yang kuat di 
masa mendatang, tetapi juga berpotensi mendorong timbulnya konflik sosial yang dapat mengancam integrasi negara-bangsa. Maka yang perlu kita lakukan saat ini adalah mencari solusi untuk mengelola kemultikulturan bangsa Indonesia. Dalam mengelola kemultikultuan cara pandang kita harus dirubah yaitu menjaga kemultikulturan tidak hanya menjadi tanggung jawab dari pemerintah pusat tetapi tanggung jawab seluruh warga negara Indonesia termasuk masyarakat pedesaan. Hal ini sejalan dengan pandangannya (Yudiana, 2017) dan (Wicaksono, dkk., 2018) yang mengatakan desa merupakan representative dari kemultikulturan Indonesia.

Desa Patoman merupakan desa dengan tingkat kemultikulturan yang tinggi. Mulai dari agama Islam dengan jumlah $82.3 \%$, Hindu mencapai $17.3 \%$, Kristen sebanyak 8 jiwa, Buddha 7 Jiwa dan kepercayaan khususnya kejawen. Dilihat dari etnik seperti Madura, Jawa, Bali, dan Osing. Dengan kemultikulturannya saat ini bukan hal yang niscaya kalau sewaktuwaktu bisa saja menimbulkan perpecahan. Solusi yang bisa ditawarkan untuk mencegah perpecahan adalah dengan menjadikan Desa Patoman Sebagai Desa Wisata berbasiskan kemultikulturan.

Potensi untuk mengembangkan desa wisata bebasis multikultur di desa patoman sangat besar karena desa Patoman terdiri dari berbagai Agama, suku bangsa, dan etnik, serta terdiri dari berbagai budaya dan seni. Bila dilihat dari eksternal didukung beberapa indikator, seperti hasil pertanian, kerajinan kulit, dan berbagai jenis UMKM serta dekat dengan aktivitas Bandara. Selain itu dengan adanya pengembangan desa wisata secara tidak langsung akan berpengaruh terhadap pendapatan masyarakat desa. Analisis lain yang dapat dijadikan sebagai dasar pengembangan desa wisata berbasis multikultur di Desa Patoman adalah tujuan dan motivasi wisatawan melakukan perjalanan wisata yaitu mencari pengetahuan atau seuatu yang baru dan unik yang tidak ada di daerah asalnya. Pengembangan desa wisata berbasis multikultur ini merupakan suatu yang unik karena tidak semua daerah mampu mengembangkan konsep pariwisata alternative seperti ini.

Kajian inspiratif dari desa wisata datang dari desa tetangga yaitu kawasan Desa Bandungan adalah salah satu potensi desa wisata yang dimiliki oleh Kabupaten
Pamekasan yang terletak di Kecamatan Pakong, Desa Bandungan ini memiliki bentangan lahan perhatian yang luas yang bisa di manfaatkan sebagai objek wisata alam dan berbagi komoditi hasil tani. Selain itu, Desa Bandungan juga memiliki keaslian, keunikan, sifat khas dari segi bangunan, sosial dan budaya. Potensi ini masih belum di manfaatkan dan dikembangkan oleh masyarakat setempat sampai saat ini. Dalam penelitian ini dilakukan penentuan faktor-faktor yang dapat mendukung pengembangan kawasan desa wisata dan perumusan konsep pengembangan kawasan desa wisata di Desa Bandungan. Tujuan penelitian ini adalah untuk menentukan konsep pengembangan kawasan desa wisata di Desa Bandungan Kecamatan Pakong, Kabupaten Pamekasan. Penelitian ini menggunakan pendekatan rasionalistik. Teknik analisa yang akan digunakan untuk mencapai tujuan dan sasaran antara lain pada sasaran pertama dengan menggunakan statistik deskriptif. Pada sasaran kedua menggunakan analisa skoring, dilanjutkan analisa delphi bertujuan untuk menentukan konsensus grup untuk faktor pendukung, pada sasaran keempat menggunakan analisis triangulasi untuk merumuskan konsep pengembangan. Penelitian ini menghasilkan konsep pengembangan secara spasial dan non spasial. Adapun konsep spasialnya dengan menyediakan rute perjalanan wisata, menyediakan sarana transportasi khusus menuju kawasan desa wisata dan menyediakan fasilitasw pendukung kegiatan wisata. Sedangkan konsep non spasialnya dengan menjadikan adat istiadat sebagai peraturan kegiatan wisata, mengembangkan kawasan desa wisata berbasis agrowisata, menyediakan fasilitas penginapan berkonsep tanean lanjheng, menyediakan toko souvenir, menyediakan fasilitas rumah makan, memberikan pelatihan kepada masyarakat, menyediakan tempat rekreasi, membuat web tentang kawasan desa wisata, melibatkan masyarakat dalam proses pengembangan dan menerapkan peraturan zonasi (Zakaria dan Suprihardjo, 2014).

Kabupaten Banyuwangi melalui bauran promosi sudah memberikan dampak positif terhadap kunjungan wisatawan namun belum cukup efektif untuk memeratakan kunjungan wisatawan dan meningkatkan lama tinggal wisatawan. Program-program advertising dan direct marketing yang dilakukan sudah efektif 
sedangkan sales promotion dan public relation belum cukup efektif (Betari Avinda, C., dkk, 2016). Dalam pelaksanaan strategi promosi juga terdapat faktor pendukung dan penghambat. Dari hasil analisis tujuan penelitian ini merekomendasikan kepada Dinas Kebudayaan dan Pariwisata untuk mengkaji ulang program bauran promosi yang kurang efektif, mengadakan pelatihan kepramuwisataan, memperbanyak Tourist Information Center, serta menjalin kerjasama dengan stakeholder lainnya. Selain itu tujuan pengembangan desa wisata patoman sebagai desa wisata merupakan salah satu sektor yang potensial untuk dikembangkan pada masa modern sekarang ini, namun tidak semua tempat wisata dapat berkembang dengan baik. Salah satu faktor yang menyebabkan kurang berkembangnya tempat wisata adalah kurangnya promosi atau penyampaian informasi kepada para wisatawan (Nisa dan Supriyanta, 2015). Perkembangan internet sekarang ini semakin maju sehingga banyak dimanfaatkan oleh pengelola tempat wisata sebagai media informasi dan promosi. Patoman sebagai desa wisata memiliki potensi untuk lebih berkembang.

\section{METODE}

Penelitian ini menggunakan metode penelitian kualitatif. Adapun strategi yang digunakan dalam penelitian ini adalah studi kasus (case study). Mengingat lokasi penelitian ini hanya di satu desa dengan kekhususannya, maka studi ini merupakan penelitian dengan strategi kasus tunggal (Sutopo, 2006). Adapun tahapan penelitian ini terdiri dari

Penelitian ini dilakukan di Desa Patoman, Blimbingsari, Banyuwangi. Pemilihan Desa Patoman sebagai lokasi penelitian didasari oleh beberapa alasan: 1) Masyarakat Desa terdiri dari berbagai macam suku, yaitu Osing, Jawa, Madura dan Bali; 2) Penduduk Desa Patoman multiagama; 3) Memiliki nilai strategis untuk dikembangkan menjadi Desa Wisata.

Teknik penentuan informan dalam penelitian ini adalah purposive sampling, yakni pemilihan informan atau sampel yang sesuai dengan tujuan peneliti (Mulyana, 2004). Menurut Sugiyono, (2009) pemilihan informan dengan metode purposive sampling berdasarkan petimbangan tertentu, misalnya orang tersebut yang dianggap paling tahu tentang apa yang kita harapkan, atau mungkin dia sebagai penguasa sehingga akan memudahkan peneliti menjelajah situasi sosial yang diteliti. Informan dalam penelitian ini adalah orangorang yang memiliki banyak pengetahuan tentang objek penelitian, yakni kepala desa, tetua/sesepuh desa, pemimpin keagamaan, pemimpin suku, masyarakat umum dan lain sebagainya.

Metode pengumpulan data menggunakan beberapa teknik, yaitu 1) Teknik observasi (observation). Dalam penelitian ini peneliti menggunakan teknik observasi partisipasi. Adapun dalam penelitian ini yang diobservasi adalah tempat atau lingkungan sosial budaya masyarakat di Desa Patoman, benda-benda keagamaan di Desa Patoman, perilaku masyarakat di Desa Patoman dalam menjaga kerukunan antar/intern umat beragama, dan keadaan generasi muda dalam memaknai kerukunan antar umat beragama di Desa Patoman. 2) Teknik wawancara (interview). Adapun dalam penelitian ini aspek-aspek yang akan diwawancarai antara lain menyangkut latar belakang masyarakat tetap menjaga kerukunan antar umat beragama, bentuk kerukunan antar umat beragama, cara masyarakat mempertahankan kerukunan antar umat beragama dan nilai-nilai karakter yang terkandung di dalam kerukunan antar umat beragama pada masyarakat multikultur di Desa Patoman. 3) Tekni Studi Dokumen Dalam penelitian ini, peneliti juga menggunakan studi dokumen untuk pengumpulan data yang bersumber dari arsip dan dokumen yang ada hubungannya dengan penelitian ini, seperti majalah, Koran, hasil penelitian, artikel dan bukubuku yang ada kaitannya dengan kerukunan antar umat beragama pada masyarakat multikultur di Desa Patoman.

Dalam penelitian kualitatif peneliti merupakan instrumen utama yang terjun ke lapangan serta berusaha sendiri mengumpulkan informasi melalui observasi, wawancara, dan studi dokumen (Sugiyono, 2009). Peneliti kualitatif sebagai human instrument, berfungsi menetapkan fokus penelitian, memilih informan sebagai sumber data, melakukan pengumpulan data, menilai kualitas data, analisis data, menafsirkan data dan membuat kesimpulan atas temuannya (Sugiyono, 2009). Berdasarkan penjelasan tersebut maka dalam penelitian ini peneliti merupakan instrument utama. Peneliti dalam pengumpulan data juga menggunakan beberapa instrumen penelitian antara lain: 
(1) pedoman observasi, (3) taperecorder, (4) buku catatan.

Dalam pengujian keabsahan data, peneliti menggunakan teknik triangulasi, yang terdiri dari: 1) Triangulasi sumber data dilakukan dengan cara menguji keabsahan sumber data yang diperoleh melalui wawancara, studi dokumen, maupun observasi. 2) Trianggulasi metode adalah teknik trianggulasi yang dilakukan dengan mengumpulkan data sejenis dengan menggunakan metode yang berbeda. Data sejenis yang dikumpulkan dengan metode yang berbeda dibandingkan dan ditarik simpulan data yang lebih kuat validitasnya (Sutopo, 2006). Triangulasi teori dilakukan dengan menggunakan pola, hubungan, dan menyertakan penjelasan yang muncul dari analisis untuk mencari tema atau penjelasan pembanding (Bungin, 2009).

Analisis data adalah proses mencari dan menyusun secara sistematis data yang diperoleh dari hasil wawancara, catatan lapangan, dan dokumentasi, dengan cara mengorganisasikan data ke dalam kategori, menjabarkan ke dalam unit-unit, melakukan sintesa, menyusun ke dalam pola, memilih mana yang penting dan yang akan dipelajari, dan membuat kesimpulan (Sugiyono, 2009). Dalam penelitian ini analisis yang digunakan adalah teknik analisis interaktif, yaitu setiap data yang diperoleh dari lapangan selalu diinteraksikan atau dibandingkan dengan unit data yang lain. Menurut Nasution (1996) dalam aktivitas menganalisis data dalam penelitian kualitatif terdapat langkah-langkah umum yang harus diikuti yakni, reduksi data (data reduction), display data (data display), dan mengambil kesimpuan dan verifikasi (conclusion drawing/verifikation).

\section{HASIL DAN PEMBAHASAN Wujud Multikultural Masyarakat Desa Patoman}

Tingkat keragaman bangsa Indonesia yang tinggi merupakan sumbu yang mudah tersulut oleh konfrontasikonfrontasi SARA. Oleh karena itu, butuh sebuah penelaan konfrehensif berkaitan dengan ciri kebhinekaan Indonesia. Suatu kajian tentang keanekaragaman budaya bukan hanya memberikan gambaran komprehensif namun lebih dari itu,dapat menumbuhkan dialog persepsi kerukunan SARA ditengah kehidupan berbangsa. Multikulturalisme merupakan given dari Tuhan, namun Bhineka Tunggal Ika merupakan titipan dari nenek moyang kita yang harus di jaga dan dilestarikan (Lestari, 2015). Indonesia yang masyarakatnya terdiri dari beraneka ragam latar belakang memerlukan nilai-nilai multikultural tertentu agar bisa saling hidup berdampingan dengan damai dan saling menghormati. Untuk menanamkan nilai-nilai tersebut di dalam masyarakat, pariwisata memegang peranan penting dan strategis. Karena melalui pariwisata, nilai multikultural itu akan tersampaikan secara tersirat (Aly, 2015).

Indonesia merupakan negara yang multikultural. Hal ini menjadikan Indonesia sangat rentan terkena konflik antaretnis atau antaragama. Untuk menghindari konflik tersebut diperlukan toleransi untuk menjaga kerukunan antara umat beragama. Salah satu daerah yang dapat memelihara toleransi dan kerukunan tersebut adalah Patoman merupakan kampung yang penuh sejarah penduduk desa tersebut mampu berbaur dan berinteraksi dengan baik pada warga Patoman lainnya yang multiagama. ketertarikan tujuan untuk mencari komunikasi lintas budaya seperti apa yang terjadi antara penduduk yang berbeda agama sehingga kerukunan dapat terus terjaga disana menjadi dasar multikural value yang perlu di tindak lanjuti guna menjawab kebituhan jaman. Akulturasi ini menandakan bahwa interaksi yang terbentuk antara berbagai kelompok agama merupakan pola interaksi asosiatif, sehingga tidak terjadi konflik seperti yang terdapat pada daerah lain sebab etika sosial menjadi kunci kemultikulturan (Paramita, S. dan Sari, 2016).

Untuk mengungkap lebih dalam fungsi etika sosial masyarakat Kotesan sebagai contohnya masyarakatnya tidak hanya memegang teguh ajaran agama tetapi juga etikasosial di dalam bermasyarakat yang terwujud dalam kerukunan umat beragama di Desa Kotesan, Prambanan, Klaten, Jawa Tengah. Penelitian Dermawan, A. dan Nadia, (2015) di Desa Kotesan, Prambanan, Klaten, Jawa Tengah merupakan penelitian kualitatif dengan pendekatan sosio-antropologis, yakni mencermati fenomena sosial-budaya yangberkembang di Kotesan sekaligus dan mencaritahu bagaimana masyarakat tersebut memaknaifenomena itu. Setting penelitian adalah Desa Kotesan, Kecamatan Prambanan, KabupatenKlaten, Provinsi Jawa Tengah yang merupakan masyarakat multikultural dari aspek keyakinanagama. Teknik pengumpulan data menggunakan wawancara mendalam dan Focus 
GroupDiscussion (FGD). Teknik analisis data menggunakan analisis interaktif berupa reduksi data,penyajian data dan penarikan kesimpulan. Hasil penelitian ini menunjukkan etika sosialmasyarakat desa Kotesan mempunyai signifikansi besar dalam rangka merajut hubungan sosialdan pengelolaan konflik yang ada di dalam masyarakat. Etika sosial yang terbangun di desaKotesan disebabkan oleh adanya persamaan konsepsi tentang ajaran leluhur yang menuntuthidup rukun, aman dan damai serta sebagai simbol kesetiaan dan kepatuhan dalam memeliharadan menjaga warisan leluhur yang mereka takzimi. Secara faktual menunjukkan tidak adapemisahan yang signifikan antara warga muslim dan warga yang nonmuslim di desa Kotesan,dalam pengertian tidak ada daerah muslim, daerah Kristen dan daerah Budha. Meski berbedabedaagama, tetapi mereka merasa berasal dari satu nenek moyang yang sama, merasa masihsatu darah atau keturunan. Sikap toleransi menjadi kunci bagi masyarakat Kotesan yang hidupdalam suasana harmonis.Meski diakui, sikap toleransi ini juga menyebabkan perpindahanagama (konversi agama) menjadi hal yang biasa. Hal ini juga berlaku di desa Patoman.

Untuk melihat lebih jelas bentuk atau wujud multikultural masyarakat desa Patoman dapat dilihat pada nilai-nilai multikultural yang hidup dalam kehidupan sosio-kultural. Hal ini menjadi sangat penting mengingat massyarakat desa Patoman sudah mampu dalam menjaga keharmonissan ditengah kemultikulturan agama, etnis, suku, bangsa, dan budaya. Nilai adalah konsepsi (tersurat atau tersirat, yang sifatnya membedakan individu atau ciri-ciri kelompok) dari apa yang diinginkan, yang mempengaruhi tindakan pilihan terhadap cara, tujuan antara dan tujuan akhir (Kluckhohn, Brameld, 1957). Definisi yang dikemukakan oleh Klukhon ini berimplikasi terhadap pemaknaan nilai-nilai budaya, seperti yang diungkap oleh Brameld dalam bukunya tentang landasan-landasan budaya pendidikan. Kattsoff dalam Soejono Soemargono (2004) mengatakan bahwa nilai itu sangat erat kaitannya dengan kebaikan atau dengan kata "baik", walaupun fakta baiknya, bisa berbeda-beda satu sama yang lainnya. Dalam kehidupan sehari-hari bagaimana sebenarnya nilai bisa ditransformasikan menjadi bagian diri individua tau kelompok sehingga menjadi karakter.
Sebagai identitas atau jati diri bangsa, karakter merupakan nilai dasar perilaku yang menjadi acuan tata nilai interaksi antar manusia. Secara universal berbagai karakter dirumuskan sebagai nilai hidup bersama berdasarkan atas pilar kedamaian (peace), menghargai (respect), kerjasama (cooperation), kebebasan (freedom), kebahagiaan (happiness), kejujuran (honesty), kerendahan hati (humility), kasih sayang (love), tanggung jawab (responsibility), kesederhanaan (simplicity), toleransi (tolerance), dan persatuan (unity). (Samani dan Hariyanto 2011).

Bagaimana dengan nilai-nilai yang terkandung dalam kemultikulturan masyarakat desa patoman yang bisa ditranformasikan dalam bentuk karakter dan dijadikan pola pikir, ucap, dan tindakan bagi warga masyarakat desa patoman sendiri? Terkait dengan hal itu maka perlu digali nilai-nilai yang terkandung dalam kemultikulturan tersebut. Dalam menggali nilai-nilai tersebut diperlukan analisis kritis dan mendalam sehingga didapatkan nialinilai yang bisa berlaku secara universal dan pleksibel. Berdasarkan pada hasil analisis kritis terhadap sosiokultur masyarakat Desa Patoman dan Forum Group Disscussion (FGD) yang telah dilakukan maka ditentukan beberapa nilai-nilai yang terkandung dalam kemultikulturan masyarakat Desa Patoman, antara lain: Nilai Religius, Sosial, Kearifin Lokal, Nasionalisme, Nilai Sosio-kultural, dan Gotong Royong.

Nilai religius yang ada dalam masyarakat multikultur di Desa Patoman ditandai dengan adanya beberapa bangunan suci dari beberapa agama yang ada di desa tersebut. Seperti masjid, musola, dan pura. Dalam pelaksanaan sehari-hari masing-masing agama dapat dengan bebas menjalankan ajaran dan agama yang dianutnnya. hal ini sesuai dengan amalan Pancasila sila perama yaitu Ketuhan Yang Maha Esa. Selain pura di Desa Patoman yang memang memiliki jumlah penduduk mayoritas Islam tentunya juga sangat banyak Masjid dan musola yang tersebar di beberapa titik di Dsea Patoman. Sebagai kelompok yang mayoritas masyarakat yang berkeyakinan Islam juga menjamin kebebasn dari umat agama lain. Adanya masjid dan musolo ini juga menunjukkan sifat religious dari masyarakat yang beragama Islam. Tidak hanya sebatas itu keberadaan masjid tidak hanya sebagai tempat ibadah sehari-hari tetapi juga 
dijadikan sebagai tempat untuk melakukan beberapa kegiatan seperti pengajian dan juga TPQ bagi anak-anak dilingkungan Desa patoman. Disamping itu juga dalam menjaga religiusitas etnik Bali yang ada di Patoman selalu berlandaskan pada kearifan local Tri Hita Karana teruta sekali adalah unsur prahyangan. Pada unsur Parahyangan diwujudkan dengan satu unit pura tertentu yang mencerminkan unsur Ketuhanan.

Dalam kehidupan social masyarakat desa Patoman dapat dikatakan berasaskan pada kegotongroyongan. Masyarakat bahu membahu dan saling tolong menolong satu sama lain dalam beberapa kegiatan, seperti kerja bakti dilingkungan Desa Patoman, membenahi sarana dan prasarana umum, bahkan ada yang saling berkunjung ketika mempunyai hajatan atau upacara. Kehidupan social ini tidak hanya terjadi dalam inter etnik atau agama saja melainkan antaretnik dan agama maupun budaya yang ada di Desa Patoman.

Sosio-kultural yang dimaksud dalam kasus ini adalah kebiasaan-kebiasaan yang sudah membudaya dalam kehidupan seharihari masyarakat Desa Patoman yang meliputi beberapa konsep, yaitu simpati, toleransi, dan empati dan gotong royong. Meminjam pendapatnya Johnson dkk (1983) mengemukakan bahwa empati adalah kecenderungan untuk memahami kondisi atau keadaan pikiran orang lain. Sedangkan Batson dan Coke (Brigham, 1991) mendefinisikan empati sebagai suatu keadaan emosional yang dimiliki oleh seseorang yang sesuai dengan apa yang dirasakan oleh orang lain. Dalam setiap melaksanakan kegiatan upacara agama umat Hindu yang ada di desa Patoman biasanya selalu melibatkan masyarakat yang Bergama islam. Atau paling tidak kita memberitahukan kepada tokoh masyarakat lintas agama yang ada di Desa Patoman. Selain itu keterlibatan para pemuda dari agama Islam dalam kegiatan upacara juga kami lakukan, misalnya adalah pada saat menjelang perayaan hari raya Nyepi pada malam pengrupukan untuk menjaga keamanan dan parkir kendaraan masyarakat yang menonton pawai ogohogoh. Selain itu pada saat perayaan hari raya nyepi-pun khusus untuk wilayah Patoman Tengah jalan akan ditutup selama 24 jam dan masyarakat beragama lainpun sangat menhormati hal ini.

Kehidupan masyarakat Desa Patoman tidak dapat dilepaskan dari adanya kegiatan kegotong royongan baik interetnik maupun antaretnik. Hal ini menjadi suatu keharusan apalagi untuk orang-orang Bali yang ada di Patoman. Gotong royong dalam masyarakat Bali yang ada di patoman sangat terlohat jelas pada saat akanada upacara di pura. Biasanya orang-orang Bali akan gotongroyong dalam menyiapkan rangkaian upacara yang akan dilaksanakan. Selain itu juga gotong royong seringkali dilakukan pada saat perayaan hari raya nyepi misalnya dalam pembuatan ogohogoh maupun dan mengarak ogoh-ogoh.

Terkait dengan gotong royong yang ada di Desa Patoman dapat dikatakan memiliki keunikan tersendiri, yaitu Gotong royong tidak hanya dilakukan oleh inter etnik saja tetapi juga antar etnik. Hal ini disampaikan oleh bapak Made Swastika selaku tokoh masyarakat mengatakan bahwa "Masyarakat dan pemuda etnik lain biasanya juga membantu proses upacara yang akan kami lakukan. Mereka biasanya selain ikut membantu menjaga keamanan juga biasanya ikut menjaga parker kendaraan."

Kearifan lokal yang fungsional bagi masyarakat, diwariskan secara turun temurun sehingga terbentuk tradisi. Hal ini sejalan dengan makana kata tradisi, yakni berasal dari bahasa latin tradere yasng berarti memindahkan atau memberi sesuatu kepada orang lain untuk disimpan (Giddens, 2003). Kearifan lokal baik yang berwujud kearifan social maupun ekologi berfungsi sebagai resep bertindak bagi manusia di lingkungan social dan lingkungan alam (skala dan niskala). Kearifan lokal yang ada di desa patoman lebih banyak ditemukan pada masyarakat Desa Patoman Tengah. Hal ini karena sebagin besar penduduk desa Patoman Tengah adalah keturunan Bali. Oleh karena itu juga Patoman Tengah sering desa sebut dengan istilah Bali Van Java atau miniature Bali.

Kearifan lokal sering diabstraksikan dan tersimpan dalam aneka ungkapan tradisional, misalnya sesonggan (pepatah), sasenggakan (ibarat), sloka, dal lain-lain. Ungkapan tradisional merupakan kalimat pendek yang disarikan dari pengalaman ynag panjang. Dia bisa saja merupakan pengalaman individual namun berubah menjadi kearifan sosial yang dipahami oleh banyak orang. Karena itu, ungkapan tradisional merupakan "kebijaksanaan orang banyak yang merupakan kecerdasan seseorang" (Danandjaja, 1982). Kearifan lokal lainnya, terutama yang terkait dengan 
kearifan sosial dalam rangka menggalang integrasi sosial, tercermin dalam konsep menyama braya, konsep ini memiliki makna pentingnya soladaritas sosial bagi kelangsungan hidup sistem sosial. Pembentukan sistem soaila yang integrative dan berkedamaian tidak dapat dilepaskan dari asas menyama braya. Apalagi pada masyarakt Bali asas menyama braya sangat diperlukan karena secara factual mereka berdiferensiasi sosial atas dasar kelas, wangsa, soroh, aliran keagamaan, partai politik, dan lain-lain.

Sebagai konsep sosial, nasionalisme tidak muncul dengan begitu saja tanpa proses evolusi makna melalui media bahasa. Nasional adalah sesuatu yang berhubungan dengan kata latin natio, yang artinya kelahiran, suku, bangsa dan nasion yang berarti pula masyarakat yang sudah berkembang sedemikianrupa sehingga mempunyai kesamaan sejarah, tradisi, kebudayaan, bahasa dan biasanya ditambah satu hal lagi yaitu wilayah (Sukanto, 2016). Lebih lanjut menurut Sukamto (2016) mengatakan bahwa Kata nasionalisme mencakup dua arti: Pertama, dalam arti nasionalistis dimaksudkan suatu sikap yang keterlaluan, sempit dan sombong. Nasionalisme yang demikian sering disebut Jinggo Nasionalism atau Chauvinism. Dan kedua, nasionalisme dapat juga menandakan sikap nasional yang positif yakni mempertahankan kemerdekaan dan harga diri bangsa, dan sekaligus mcnghormati bangsa lain. Inilah kebangsaan yang luas pandangannya serta dewasa dan adil.

Desa merupakan representative dari ke-Indonesian kita karena pada hakekatnya ada beberapa desa juga bersifat multikultur. Oleh karena itu dalam menjaga kemultikulturan sebagai kekayaan bangsa seharusnya tidak hanya dibebankan kepada pemerintah pusat semata, tetapi juga menjadi tugas dan kewajiban semua kalangan yang masih berada dalam lingkup Negara Kesatuan Republik Indonesia. Permasalahannya adalah bagaimana caranya menjaga kemultikulturan kita? Pertanyaan ini terjawab ketika kita melihat keadaan sosio-kultural masyarakat desa Patoman. Di Desa Patoman kemultikulturan bukanlah sebuah ancaman, melainkan adalah sebuah kekuatan.
$\begin{array}{llll}\text { Model Desa } & \text { Wisata } & \text { Berbasis } \\ \text { Multikulturalisme di } & \text { Desa } & \text { Patoman, }\end{array}$ Blimbingsari, Banyuwangi

Model

pengembangan kepariwisataan sebagai dasar teori antara lain dibahas oleh Gunn (1972). Gunn lebih sarat dengan aspek-aspek ekonomi, yang mengemukakan keterkaitan antara sisi sediaan (supply) dengan permintaan (demand) serta faktorfaktor eksternal yang mempengaruhinya. Lebih lanjut Gunn mengidentifikasi beberapa factor eksternal yang mempengaruhi perkembangan pariwisata, yaitu sumber daya alam, sumber daya budaya, organisasi/kepemimpinan, keuangan, tenaga kerja, kewirausahaan, masyarakat, kompetisi, dan kebijakan pemerintah (Gunn 2002).

Selain itu, Mill dan Morrison (1985) mengatakan model pengembangan kepariwisataan yang mengaitkannya dengan konteks proses perencanaan/ pengelolaan pariwisata, yang kemudian dikembangkan pada tahun 1992. Milld dan Morrison mengungkapkan empat komponen pembentuk system kepariwisataan, yaitu market (pasar), marketing (pemasaran), destination (destinasi/daerah tujuan wisata), dan travel (perjalanan). Market (pasar): mencakup faktor-faktor yang mempengaruhi pasar dengan penekanan pada perilaku pasar, faktor-faktor internal dan eksternal yang mempengaruhi perjalanan wisata, dan proses pengambilan keputusan berwisata. Marketing (pemasaran): menfokuskan pada strategi bagaimana pengelola pariwisata merencanakan, mempromosikan, dan mendistribusikan barang dan jasa kepada wisatawan. Travel (perjalanan): fokus pada pergerakan wisatawan, moda transportasi, dan segmen pasar. Destination (destinasi/daerah tujuan wisata): mencakup proses dan prosedur yang dilakukan oleh destinasi pariwisata dalam pembangunan dan mempertahankan keberlanjutan kepariwisataan.

Lebih lanjut menurut Sukadijo (2000) Dalam industri pariwisata, terdapat sejumlah variabel, yaitu konsumen, produsen, demand, dan suply, yang hubungan relasionalnya. Model pengembangan pariwisata lain adalah The Global Tourism System (Cornelissen, 2005). Cornelissen mengemukakan bahwa pariwisata global memerlukan pasar yang berbeda/spesifik didasarkan pada pertukaran antara produsen dan konsumen pariwisata. Pada sisi permintaan (demand), hal tersebut terdiri dari kelompok-kelompok sosial dengan karakteristik sosial ekonomi dan sosial budaya, minat, kebutuhan, dan keinginan tertentu. Pada sisi sediaan 
(supply) terdiri dari produsen-produsen yang berinteraksi, inovasi, dan bersaing. Keterkaitan antara produsen dimonitor dan diatur oleh lembaga-lembaga yang mengatur perkembangan/ berjalannya pariwisata (Cornelissen 2005).

$$
\text { Dalam kaitannya dengan }
$$

pengembangan Desa Wisata berbasis multikulturalisme nampaknya tidak hanya cukup dengan memakai salah satu jenis model pengembangan dari teori-teori di atas tetapi harus dilakukan modifikasi dari teori model pengembangan pariwisata tersebut. Untuk itu dalam melakukan modifikasi harus

Pengertian terpadu disini adalah memadukan antara potensi yang dimiliki oleh desa Patoman dengan jenis pariwisata lainnya seperti pariwisata alam, budaya, sejarah, ekowisata, agrowisata, desa wisata, dan atraksi-atraksi wisata lainnya. Dengan model pengembangan seperti ini akan sangat menyesuaikan dengan kebutuhan wisatawan. Model ini memiliki kemiripan dengan konsep pariwisata utama dan ditentukan terlebih dahulu indikator-indikator yang akan dijadikan sebagai dasar untuk mengembangkan model desa wisata berbasis multicultural. Indicator tersebut secara jelas sudah di jabarkan dalam analisis SWOT yang sudah dilakukan. Berdasarkan analisis SWOT dan FGD yang sudah dilakukan, serta berbgai litertur tentang model pengambangan pariwisata maka model yang tepat untuk pengembangan desa wisata berbassis multikultural di Desa Patoman, Kecamatan Blimbingsari, Banyuwangi adalah terpadu dan berkelanjutan.

pendukung. Dengan model seperti dalam sekali kunjungan wisatawan tidak akan jenuh karena akan disuguhkan dengan berbagai jenis potensi wisata yang akan dikemas dalam jadwal kunjungan. Untuk lebih jelas kerangka model desa wisata berbasis mltikultural di Desa Patoman, Blimbingsari, Banyuwangi dapat dilihat pada gambar berikut ini.

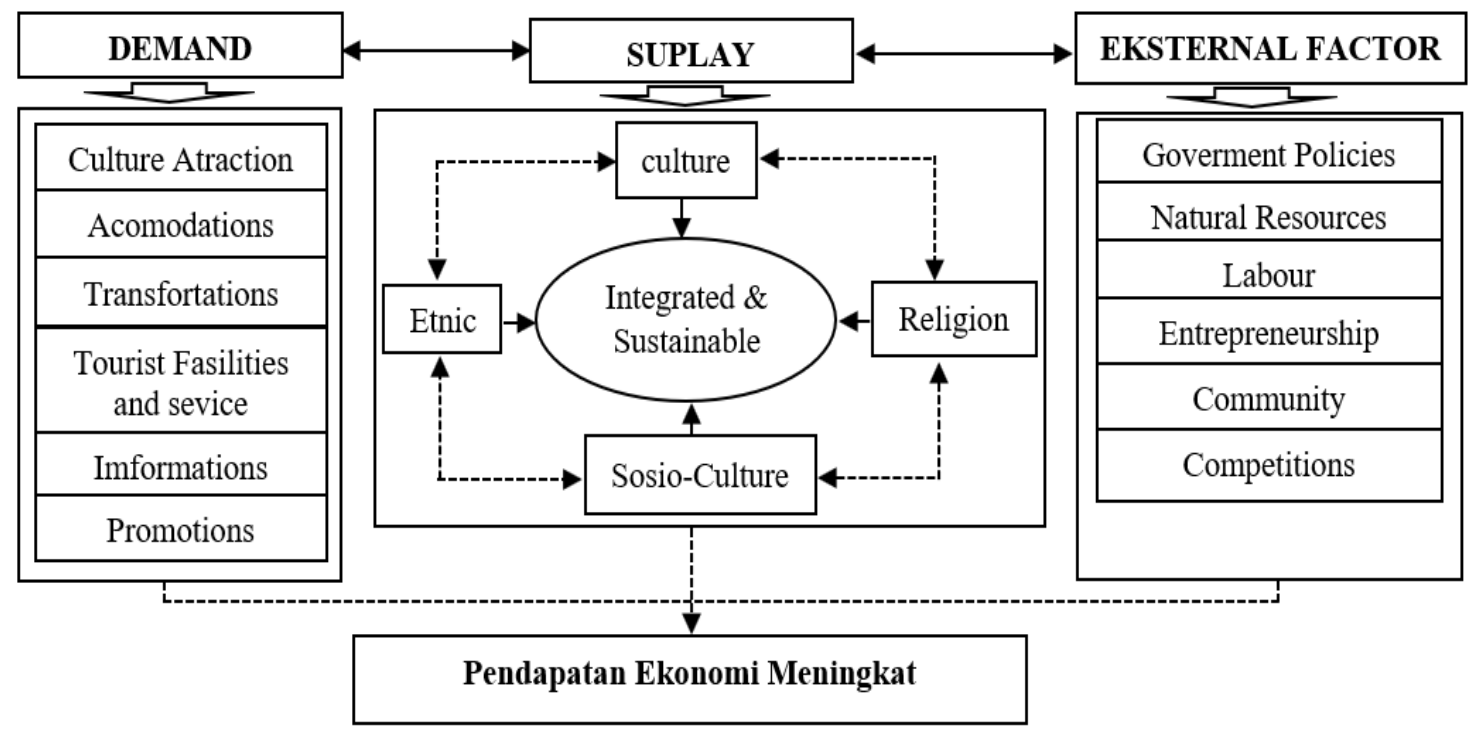

Gambar 1. Model Desa Wisata Terpadu Berbasis Multikultur Sumber. Data Primer Penulis, 2019

Menurut Gunn (1988) sistem fungsional pariwisata melalui pendekatan Demand dan Supply. Dari sisi demand komponen pariwisata adalah masyarakat atau pasar wisata yang memiliki kemauan dan kemampuan untuk melakukan perjalanan wisata. Sementara itudari sisi supply komponen pariwisata terdiri atas atraksi dan pelayanan wisata, transportasi serta informasi dan promosiwisata yang semuanya ada dalam suatu wilayah pariwisata.
Analisis Kesesuaian Permintaan (demand) Wisatawandan Penawaran (supply) Obyek Wisata pengembangan atraksi wisata hakekatnya menekankan pada analisis terhadap kondisi pemuasan (satisfying) antara kebutuhan/permintaan (demand) denganpenyediaan/penawaran (suply) Perencanaandan pengembangan kegiatan wisata pada suatu wilayah memang perlu mengusahakan keterpaduan antar dua komponen utama pengembangan yaitu sisi permintaan (demandside) dan sisi 
penawaran (supply side). Pendekatan ini merupakan salah satu pendekatan yang sangat mendasar, karena pada hakekatnya perencanaan danpengembangan suatu obyek dan daya tarikwisata tidak lain ditujukkan untuk menarikkunjungan wisatawan ke suatu obyek. Sehingga pengembangan yang akan dilakukanharus memperhatikan dan mendasarkan padakajian terhadap kesesuaian antarakarakteristiksisi penawaran. Obyekwisata dengan karakteristik sisi permintaan pengunjung. Kesesuaian antara Permintaan (demand) dan Penawaran (supply) akan berdampak pada kepuasan wisatawan yang pada akhirnya mampu menciptakan nilai jual dan meningkatkan daya saing obyek wisata (Cravens, 1997). Oleh karena itu pendekatan pengembangan tidak bisa hanya berangkat dari sisi produk atau sisi penawaran saja (product driven), sehingga dengan pendekatan ini produk yang dikembalikan akan dapat diterima dan diapresiasi oleh pasarwisatawan.

Pada gambar 01 dijelaskan ada tiga indikator utama dalam pengembangan model desa wisata berbasis multikultur di desa patoman, yaitu Demand, suplay, dan faktor ekternal. Ketiga indikator tersebut didapat dengan melakukan analisis terhadapat berbagai kekuatan, kelemahan, peluang, dan ancaman (SWOT) yang sudah dilakukan. Suplay memiliki peran penting $\mathrm{dlm}$ pengembangan sebuah destinasi pariwisata karena berkaitan dengan potensi yang bisa kita kembangkan atau jual kepada wisatawan. Dalam pengambangan de wiata berbasi multikultur di Desa Patoman, Blimbingsari, Banyuwangi. Suplay yang dimiliki oleh desa Patoman yang dapat dijadikan sebagai amunisi utama dalam mengembangkan desa wissata berbasis multikultur antara lain: budaya, agama, kesenian, sosio-kultural, dan etnik. Sedangkan untuk Demand terdiri berupa Culture Atraction, Acomodations, Transfortations, Imformations, Tourist Fasilities and sevice dan, Promotions. Suplay dan demand akan dipengaruhinoleh faktor ekstern seperti: Goverment Policies, Natural Resources, Labour, Entrepreneurship, Community, dan Competitions.

Adanya budaya Bali di Patoman dpat dijadikan sebagai suplay dalam mengembangkan desa wisata berbasis multikultur. Kebudayaan masyarakat Bali yang ada di Desa Patoman terlihat jelas pada bentuk bangunan rumah, tempat ibadah, cara berpakaian, dan lingkungan yang masih mengamalkan kerifan lokal Tri Hita Karana.

Dilihat dari sudut pandang agama tampaknya juga berpotensi untuk dikembangkan menjadi desa wisata berbasis multikultur. Hal ini dapat dilihat dari beberapa agama yang berkembang di desa patoman, salah satunya adalah agama hindu yang masih berpegang pada ajaran Hindu Bali. Hal ini dapat dilihat dari keberdaan tempat ibadah di desa Patoman khusus yang bergama hindu berupa kahyangan tiga berup Pura Dalem, Pura Puseh, dan Bale Agung.

Kemultikulturn ini didukung oleh sosio-kultural yang hidup dalam masyarakat desa Patoman. Hal ini terlihat jelas dalam kehidupan sehari-hari masyarakat desa Patoman. Sosio-kultural yang dimaksud dalam kasus ini adalah kebiasaankebiasaan yang sudah membudaya dalam kehidupan sehari-hari masyarakat Desa Patoman yang meliputi beberapa konsep, yaitu simpati, toleransi, dan empati dan gotong royong.

Meminjam pendapatnya Johnson dkk (1983) mengemukakan bahwa empati adalah kecenderungan untuk memahami kondisi atau keadaan pikiran orang lain. Sedangkan Batson dan Coke (Brigham, 1991) mendefinisikan empati sebagai suatu keadaan emosional yang dimiliki oleh seseorang yang sesuai dengan apa yang dirasakan oleh orang lain. Kehidupan masyarakat Desa Patoman tidak dapat dilepaskan dari adanya kegiatan kegotong royongan baik interetnik maupun antaretnik. Hal ini menjadi suatu keharusan apalagi untuk orang-orang Bali yang ada di Patoman. Gotong royong dalam masyarakat Bali yang ada di patoman sangat terlohat jelas pada saat akanada upacara di pura.

Selain itu, kearifan lokal juga menjadi salah satu suplay yang sangat penting dalam pengembangan desa wisssta berbassis multikultur di Desa Patoman. Terutama adalah kearifan lokal masyarakat Bali yang ada di Desa Patoman. Kearifan lokal yang fungsional bagi masyarakat, diwariskan secara turun temurun sehingga terbentuk tradisi. Hal ini sejalan dengan makana kata tradisi, yakni berasal dari bahasa latin tradere yasng berarti memindahkan atau memberi sesuatu kepada orang lain untuk disimpan (Giddens, 2003). Kearifan lokal baik yang berwujud kearifan social maupun ekologi berfungsi sebagai resep bertindak bagi manusia di 
lingkungan social dan lingkungan alam (skala dan niskala).

Kearifan lokal sering diabstraksikan dan tersimpan dalam aneka ungkapan tradisional, misalnya sesonggan (pepatah), sasenggakan (ibarat), sloka, dal lain-lain. Ungkapan tradisional merupakan kalimat pendek yang disarikan dari pengalaman ynag panjang. Dia bisa saja merupakan pengalaman individual namun berubah menjadi kearifan sosial yang dipahami oleh banyak orang. Karena itu, ungkapan tradisional merupakan "kebijaksanaan orang banyak yang merupakan kecerdasan seseorang" (Danandjaja, 1982). Kearifan lokal lainnya, terutama yang terkait dengan kearifan sosial dalam rangka menggalang integrasi sosial, tercermin dalam konsep menyama braya, konsep ini memiliki makna pentingnya soladaritas sosial bagi kelangsungan hidup sistem sosial. Pembentukan sistem soaila yang integrative dan berkedamaian tidak dapat dilepaskan dari asas menyama braya. Apalagi pada masyarakt Bali asas menyama braya sangat diperlukan karena secara factual mereka berdiferensiasi sosial atas dasar kelas, wangsa, soroh, aliran keagamaan, partai politik, dan lain-lain.

Sedangkan untuk Demand terdiri berupa Culture Atraction, Acomodations, Transfortations, Imformations, Tourist Fasilities and sevice dan, Promotions. Menurut Suwena (2010), atraksi atau obyek daya tarik wisata (ODTW) merupakan komponen yang signifikan dalam menarik kedatangan wisatawan. Terkait dengan atraksi budaya yang ada di Desa Patoman misalnya seperti atraksi ogoh-ogoh yang diadakan setiap malam pengrupukan sebelum hari raya Nyepi. Sedangkan atraksi rutin yang dilakukan hampir setiap hari adalah kegiatan karang taruna yang melakukan latihan nabuh, menulis Bahasa Sansekerta, dan latihan Jangeran. Selain itu juga desa patoman sudah didukung oleh akomodasi dan transfortasi yang memadai. Karena terletak di jalur utama menuju bandara udara Blimbingsari sehingga menjadi daerah yang strategis dan tepat untuk dikembangkan menjadi daerah wisata. Karena dekat dengan bandara maka secara tidak langsung informasi dan fasilitas wisatawan di Desa Patoman, Blimbingsari, Banyuwangi mudah untuk didapatkan. Yang perlu dilakukan untuk mendukung pengembangan desa wisata berbasis multikultur di Desa Patoman adalah melakukan promosi secara berkelanjutan.
Suplay dan demand akan dipengaruhinoleh faktor ekstern seperti: Goverment Policies, Natural Resources, Labour, Entrepreneurship, Community, dan Competitions. Yang paling berpengaruh dari beberapa factor eksternal tersebut adalah kebijakan pemerintah daerah dalam mengembangkan pariwisata. Tampaknya kebijakan pemerintah Banyuwangi dalam mengembangkan pariwisata dapat dikatakan sangat baik.hal ini dapat dilihat dari adanya berbagai penghargaan yang diterima oleh Pemerintah Daerah Kabupaten Banyuwangi dalam pengembangan pariwisata. Misalnya Anugerah Wisata Nusantara tahun 2011 sebagai Kabupaten terbaik daya Tarik wisata buatan dan Bupati paling peduli memajukan pariwisata daerah. Selain itu pada tahun 2016 Banyuwangi juga mendapat penghargaan internasional dalam ajang United Nations World Tourism Organization (UNWTO) Awards ke-12 yang berlangsung di Madrid, Spanyol, Rabu, 20 Januari 2016 (Bagus Prasetyo: Tempo 22/01/2016). Tidak hanya itu Banyuwangi juga menyandang gelar sebagai Kota Adipura (Bappeda Kab. Banyuwangi, 2018).

Berdasarkan pemaparan di atas modelpengembangan desa wisata berbasis multikultur di Desa Patoman,Blimbingsari,Banyuwangi yang tepat adalah dengan menggunakan model Desa wisata terpadu dan berkelanjutan.

\section{SIMPULAN DAN SARAN}

$\begin{array}{ll} & \text { Wujud kemultikulturn desa Patoman } \\ \text { terdapat pada kehidupan sosial }\end{array}$ masyarakatnya. Untuk melihat lebih jelas bentuk atau wujud multikultural masyarakat desa Patoman dapat dilihat pada nilai-nilai multikultural yang hidup dalam kehidupan sosio-kultural. Hal ini menjadi sangat penting mengingat massyarakat desa Patoman sudah mampu dalam menjaga keharmonissan ditengah kemultikulturan agama, etnis, suku, bangsa, dan budaya. Berdasarkan analisis yang sudah dilakukan terhadapat kehidupan sosial, budaya, dan lingkungan masyarakat Desa Patoman dapat diambil beberapa wujud kemultikulturan yang terintegrai kedalam nilai-nilai karakter, yaitu nilai Sosial, Sosiokultural, Religius, Nasionalisme, Gotong Royong,

Demokrasi, Bersahabat/Komunikatif, Peduli Lingkungan. Selain itu aksentuasi penelitian secara analisis menunjukkan hasil bahwa terjadi akulturasi antara warga yang multiagama tersebut. Akulturasi ini menandakan bahwa 
interaksi yang terbentuk antara berbagai kelompok agama merupakan pola interaksi asosiatif, sehingga tidak terjadi konflik seperti yang terdapat pada daerah lain.

Adapun rekomendasi yang dapat diajukan sesuai dengan hasil penelitian yang telah dijabarkan pada pembahasan di atas, sebagai berikut. Konssep pengembangan desa wisata berbasis multikultur sangat relevan diterapkan di desa Patoman, tetapi haruss dengan menggunakan konsep pembangunan desa wisata terpadu dan terintegrasi dengan potenssi desa misalkan potensi alam, budaya, dan seni. Agar pengembangan desa wisata bebasis multikultur dapat berkembang dengan baik maka perlu ditunjang dengan fasilitas-fasilitas yang dibutuhkan oleh para wisatawan baik mancanegar mau domestik.

Perlu adanya pusat informasi terpadu di dessa patoman dan tempattempat strategis seperti bandara blimbingsari ssebagai tempat untuk melakukan promosi terkait dengan keungulan desa patoman,baik itu pariwisata maupun potensi lainnya sperti UMKM, dan hasil-hasil pertanian sebagai penunjang pengembangan des wisata berbasis multikultur. Perlu adanya peningkatan atraksi budaya dan seni untuk menarik minat wisatawan berkunjung ke desa Patoman. Desa patoman perlu dijadikan sebagai model dalam mengelola kemultikulturan agar tidak terjadi konflik tetapi memberikan dampak ekonomi bagi masyarakat.

Pengembangan lingkungan perlu memperhatikan kerifan lokal agar memiliki nilai keindhan dan meningkatkan daya tarik wisatwn untuk berkunjung. Perlu adanya pelatihan bagi mayarakat umum desa Patoman dalam pengembangan sikap terkait dengan tata kram adan nilai dalam menyambut kedatangan wisatawan yang berkunjung.

\section{UCAPAN TERIMAKASIH}

Ucapan terima kasih dengan tulus dan rendah hati peneliti haturkan pada DRPM Ristek Dikti yang telah memberikan bantuan dana sehingga penelitian ini bisa terlaksana dan selesai tepat pada waktunya. Seluruh civitas akademika universitas 17 agustus banyuwangi 1945 support dan dukungannya tidak pernah terlupakan. Serta ucapan terima kasih kepada kawan-kawan dosen universitas 17 agustus banyuwangi 1945 yang tidak dapat peneliti sebut satu persatu. Berkat bantuan kawan-kawan dosen juga peneliti dapat menyelesaikan penelitian ini. Untuk itu, saya ucapkan terima kasih.

\section{DAFTAR PUSTAKA}

Aly, A. (2015) 'Studi Deskriptif Tentang NilaiNilai Multikultural Dalam Pendidikan Di Pondok Pesantren Modern Islam Assalaam', Jurnal IImiah Pesantren.

Betari Avinda, C., Sudiarta, I. N. And Oka Karini, N. M. (2016) 'Strategi Promosi Banyuwangi Sebagai Destinasi Wisata (Studi Kasus Pada Dinas Kebudayaan Dan Pariwisata)', Jurnal IPTA, 4(1), p. 10.

Bungin, H. M. (2009) Penelitian Kualitatif: Komunikasi, Ekonomi, Kebijakan Publik, dan IImu Sosial Lainnya. Jakarta: Kencana Prenada Media Group.

Dermawan, A. And Nadia, Z. (2015) 'Etika Sosial Dalam Kerukunan Umat Beragama (Studi Kasus Di Desa Kotesan Kecamatan Prambanan Kabupaten Klaten Jawa Tengah)', Humanika, 2(1), pp. 37-44.

Lestari, G. (2015) 'Bhinnekha Tunggal Ika: Khasanah Multikultural', Jurnal Pendidikan Pancasila dan Kewarganegaraan.

Mulyana, D. (2004) Metodologi Penelitian Kualitatif: Paradigma Baru IImu Komunikasi dan IImu Sosial Lainnya. Bandung: PT. Remaja Rosdakarya.

Nisa, K. dan S. (2015) 'Desa wisata Karangrejo sebagai media informasi dan promosi. Penelitian yang dilakukan untuk merancang', Jurnal Bianglala Informatika Vol 3 No 1 Maret 2015, 3(1).

Paramita, S. and Sari, W. P. (2016) 'Intercultural Communication to Preserve Harmony Between Religious Group in Jaton Village Minahasa (Komunikasi Lintas Budaya dalam Menjaga Kerukunan antara Umat Beragama di Kampung Jaton Minahasa)', Journal Pekommas.

Sugiyono (2009) Metode Penelitian Kuantitatif, Kualitatif dan R\&D. Bandung: CV. Alfabeta.

Sutopo, H. B. (2006) Metode Penelitian Kualitatif. Surakarta: Sebelas Maret University Press.

Wicaksono, Demas B. dan Dravendy R. (2018) Model Pengembangan Desa Kebangsaan Berbasis Multikultural sebagai Strategi Menjaga 
I Kadek Yudiana, Andika Wahyudiono | Pengembangan Desa Wisata Berbasis Multikultural Di Desa Patoman

Kebhinekaan di Dea Patoman,
Blimbingsari,
Banyuwangi.

Yudiana, I Kadek (2017) Analisis

Kerukunan Antar Umat beragama

Pada Msayarakat Multikultur di Ujung

Timur Pulau Jawa (Studi Kasus di

Desa Patoman, Blimbingsari,

Banyuwangi). Banyuwangi.

Zakaria, F. and Suprihardjo, D. (2014)

'Konsep Pengembangan Kawasan

Desa Wisata di Desa Bandungan

Kecamatan Pakong Kabupaten

Pamekasan', Teknik Pomits. doi:

2337-3520. 